\title{
Discretionary Accrual in the Bullish and Bearish Time Period in the Indonesian Capital Market (Study of Indonesian Manufacturing Companies)
}

\author{
Muhammad Haykal $^{1}$, Erlina $^{2}$, Azhar Maksum ${ }^{3}$ and Iskandar Muda ${ }^{4}$ \\ \{1 mhaykal@unimal.ac.id, ${ }^{2}$ erlinaroesli1966@yahoo.com, ${ }^{3}$ amaksum@yahoo.com.au ${ }^{4}$ ismuda.jurnal \\ internasional@gmail.com\} \\ ${ }^{1}$ Doctoral Student in Faculty of Economic and Business, Universitas Sumatera Utara, Indonesia, \\ ${ }^{2,3,4}$ Lectures Faculty of Economic and Business, Universitas Sumatera Utara, Indonesia
}

\begin{abstract}
Financial reporting is one of the obligations of issuers in the capital market who have sold shares to the public. This information is a signal conveyed by the company to investors about the company's financial condition. In accordance with the regulations and accounting standards in the financial reporting manager using the accrual accounting system, various manager motivations are known to be the background in delivering financial reports to the public. This research was conducted on Indonesian manufacturing companies, using the Modified Jones Model, we measured accrual discretion in financial statements. The results of the study show that accrual discretion in Indonesian manufacturing companies is carried out with a variety of motivations, especially to inform the signal of good performance to shareholders. Using the GLS panel data (cross section weights), we found evidence that the bullish time period on the Indonesian capital market was found to have a significant negative effect on discretionary accruals. This statement proves that in periods of bullish time, managers tend to convey information that meets the principles of efficient capital markets.
\end{abstract}

Keywords: Discretionary Accrual, Bullish, Bearish, Investors

\section{Introduction}

Financial reports are a means for companies to deliver relevant and useful financial information to stakeholders and shareholders. Information on financial statements is a signal delivered by the company to investors about the company's financial condition. Many company owners cannot fully believe in the financial statements submitted by the manager (Moustafa, 2015).

Good managers, for example, will pay high dividends, and tend to avoid using these funds in investments that provide low returns (Fairchild, 2010). Capital market motivation is one of the motivations of managers in conveying accounting information that is very important to investors and market analysis in making business decisions (Goel, 2015).

Accrual accounting provides information related to return stock, and determination of stock market prices. The manager uses accrual discretion in conveying the company's financial information to the capital market, and the market reacts positively to the delivery of information on contemporary corporate profits (Koerniadi and Tourani-Rad, 2011), forecasting future profits (Bernard and Skinner, 1996), reduction in product prices, opening new factories, and new marketing areas (Herbig and Milewicz, 1996), and IPO announcements to be made by the company. 
The choice of accrual method is very important for researchers to study, for users of financial statements, the compilers of accounting standards (Bernard and Skinner, 1996). Managers tend to manage the company's income so as not to report a decrease in profit value or avoid a decrease in the reported profit level. They are involved in earnings management when company profits increase or when companies are financially healthy (Ghazali, Shafie and Sanusi, 2015).

Discretionary accrual transactions give management freedom to determine the number of accrual transactions flexibly according to their motivation. Whereas non-creative accruals are accrual components that occur along with changes in company activities. Non-discretionary accrual estimates of firms from the firm's past accrual level before the period when there is no systematic earnings management. Managers prefer to use abnormal accruals and in real earnings management, this is mostly done in developing countries that do not yet have strong regulations and weak law enforcement (Zgarni, Hlioui and Zehri, 2012).

The accounting profession aims to serve the public interest, accountants must be able to understand the expectations of information users, so they must be more responsible in the future, especially in financial statements that are free from falsification of information in financial statements (Reiter, 1997).

The financial scandals of the 2000s cost investors millions to billions of US dollars, a special concern of the United States government, which caused the relevant authorities to issue the Sarbanes-Oxley law in 2002 to protect the interests of investors (Yarahmadi and Bohloli, 2015). The purpose of this law is to restore public confidence and growing trust in financial reporting by businesses, especially public companies.

The development of the Indonesian capital market during 2005 to 2016 was seen from the development of the composite stock price index (CSPI) experiencing bullish and bearish conditions. Following are developments in the Composite Stock Price Index (IHSG) and market capitalization for 11 years.

\begin{tabular}{llll} 
Tabel 1. Indonesian Capital Market Development \\
\hline Year & IHSG & $\begin{array}{l}\text { Market } \\
\text { Capitalization }\end{array}$ & $\begin{array}{l}\text { Rema } \\
\text { rk }\end{array}$ \\
\hline 2005 & $1,162$. & 801.252 .702 .092 .4 & Bullis \\
& 63 & 20 & h \\
\hline 2006 & $1,813$. & 1.249 .074 .451 .469$. & Bullis \\
& 00 & 050 & h \\
\hline 2007 & $2,745$. & 1.998 .901 .739 .979$. & Bullis \\
& 00 & 190 & h \\
\hline 2008 & $1,355$. & 1.076 .490 .533 .101$. & Bearis \\
& 00 & 380 & h \\
\hline 2009 & $2,534$. & 2.007 .000 .000 .000$. & Bullis \\
& 00 & 000 & h \\
\hline 2010 & $3,703$. & 3.257 .491 .064 .059$. & Bullis \\
& 00 & 210 & h \\
\hline 2011 & $3,821$. & 3.537 .781 .724 .361$. & Bullis \\
& 00 & 680 & h \\
\hline 2012 & $4,316$. & 4.128 .206868 .586$. & Bullis \\
& 69 & 550 & h \\
\hline 2013 & $4,274$. & 4.219 .020 .240 .968$. & Bearis \\
& 18 & 150 & h \\
\hline
\end{tabular}




\begin{tabular}{llll}
\hline 2014 & $\begin{array}{l}5,178 . \\
00\end{array}$ & $\begin{array}{l}5.228 .043 .482 .300 . \\
020\end{array}$ & $\begin{array}{l}\text { Bullis } \\
\mathrm{h}\end{array}$ \\
\hline 2015 & $4,593$. & 4.872 .701 .656 .217$. & Bearis \\
& 01 & 230 & $\mathrm{~h}$ \\
\hline 2016 & $5,296$. & 5.753 .612 .759 .029$. & Bullis \\
& 71 & 210 & $\mathrm{~h}$ \\
\hline \multicolumn{3}{c}{ Source: data processed }
\end{tabular}

In the case of companies in Indonesia we want to test, how the delivery of public company financial statements is made in accordance with the interests of the company alone or also consider the users of other financial statement information. This study not only looks at the level of importance of managers in the delivery of financial reports to the public, but also wants to find out how far the accrual discretion in the delivery of these financial statements affects the users of financial statement information in making decisions.

\section{Literature Review}

Over the past few decades agency theory has emerged as one of the dominant theories in the paradigm of financial or capital market research. Rooted in financial economics, the starting point of agency theory is in the phenomenon that in shareholding in modern companies the number of outstanding shares is scattered and separate from management control over the corporation (Grundei, 2008).

This literature, agency theory in particular has become an agency relationship agent as a contract whereby one or more people acting as principals (ie shareholders / shareholders) appoint another person as an agent (ie manager) to do services for the interests of principals, including delegating power in decision making to agents. In the agency theory accounting information is used for two purposes, first is used by the owner and agent for decision making and second is to evaluate the profit sharing in accordance with the work contract that has been made and agreed together.

Investors want to ensure that they get their money back and the return on investment that has been made, the investment is not wasted in projects that are not attractive and profitable. Therefore contracts made by managers and owners tend to be difficult to predict. Managers tend to discretion accruals to safeguard their personal interests (Grundei, 2008). Manager behavior is often influenced by education and training, certain institutions that continue to provide direction on how managers manage conflict over various interests (Bendickson et al., 2016). Conflicts between owners, governments, and workers show an increase in agency problems because most ethics and scholarship books seem to argue that managers must be more tied to stakeholders than shareholders.

\section{Methodology}

This research was conducted with descriptive quantitative methods and qualitative methods, using secondary data, namely the financial statements of manufacturing companies that have gone public on the Indonesian capital market (BEI). Data analysis was performed using Eviews, EGLS panel data.

The data used in this study are secondary data, namely financial statements that have been published by the Indonesia Stock Exchange through the ICDM starting from 2006-2016 with observations of 1879 manufacturing companies. Accrual analysis is carried out using the 
Jones Modified Model (Dechow, Sloan and Sweeney, 1995), while managerial behavior is seen with a proxy bonus scheme (Healy, 1985), ownership structure (Abukosim et al., 2014) and audit quality (Piyawiboon, 2015). Signaling motives are tested with efficient market theory using profitability analysis return on assets and earnings per share (Richardson et al., 2005) The models in this study are as follows:

Calculate Discretionary Accruals by using modified Jones models:

$T A_{i t} / A_{i t-1}=\alpha_{1}\left(1 / A_{i t-1}\right)+\beta_{1}\left\{\left(\Delta R E V_{i t} / A_{i t-1}\right)-\left(\Delta R E C_{i t} / A_{i t-1}\right)\right\}+\beta_{2}\left(P P E_{i t} / A_{i t-1}\right)+$

$\epsilon_{i t}$

Where: TA: Total accrual in the period $\mathrm{t}$; $\mathrm{TA}_{\mathrm{t}-1}$ : Total Asset in the period $\mathrm{t}-1, \Delta \mathrm{REV}$ : Changes net income in the period t; $\triangle$ REC: Change Net Receivables in the period $t$; PPE :Property, Plan and equipment; a1,a2 dan a3; Regression coefficient of equation; â1, â2 dan â3 : fitted coefficient obtained from the regression equation.

Then, in measuring the effect on the conditions of the bullish and bearish time period using the dummy model of the following variables:

$D A_{i t}=\left[\beta_{10}+\beta_{11} * S B_{i t}+\beta_{12} * N o S h_{i, t}+\beta_{13} * K A_{i, t}+\beta_{14} * R O A_{i, t}+\beta_{15} * P B V_{i, t}+\right.$

$\left.\beta_{16} * E P S_{i, t}+\beta_{17} * P E R_{i, t}+\beta_{18} * F_{S I Z E}, t\right] * D T 1$

where: DA is discretionary accrual, Nosh; number of share, ROA: return on assets , PBV; price book vakue, EPS; Earning pershare, PER; Price Earnings ratio; FSize; Firm size.

\section{Results And Discussion}

Discretionary accrual analysis using modified Jones model in 1879 observations of manufacturing companies, found that as many as $29.6 \%$ of public companies listing on the Stock Exchange conducted discretionary accruals in their financial reporting. Meanwhile, the remaining $70.4 \%$ of manufacturing companies do not carry out accrual discretion in the submission of financial reports to the public. This finding proves that Indonesian manufacturing companies in the observation period in percentage tend not to do discretionary accruals. This finding supports the research which states that poorly performing public companies in Indonesia tend to do real earnings management rather than accrual arrangements.

Based on the results of descriptive statistical testing, correlation test and Multiple Regression Analysis, the estimation of accrual discretion model can be seen in the following table:

Table 2. Multiple Regression Result

\begin{tabular}{lllll}
\hline Variable & $\begin{array}{l}\text { Coeffici } \\
\text { ent }\end{array}$ & $\begin{array}{l}\text { Std. } \\
\text { Error }\end{array}$ & $\begin{array}{l}\text { t- } \\
\text { Statistic }\end{array}$ & Prob. \\
\hline C & -0.13074 & 0.00665 & -19.6415 & 0 \\
& & 6 & & \\
\hline DSB & $7.24 \mathrm{E}-06$ & $\begin{array}{l}1.19 \mathrm{E}- \\
05\end{array}$ & 0.60606 & 0.5446 \\
& & 4 & \\
\hline DNOSH & $6.21 \mathrm{E}-10$ & $8.02 \mathrm{E}-$ & 0.77469 & 0.4386 \\
& & 10 & 8 & \\
\hline DKA & -0.00468 & 0.01019 & -0.45911 & 0.6462 \\
& & 9 & & \\
\hline
\end{tabular}




\begin{tabular}{lllll}
\hline DROA & 0.00513 & 0.00038 & 13.3024 & 0 \\
& 2 & 6 & 2 & \\
\hline DPBV & 0.00084 & 0.00142 & 0.58947 & 0.5556 \\
& 1 & 6 & 8 & \\
\hline DEPS & 0.00017 & $3.93 \mathrm{E}-$ & 4.51540 & 0 \\
& 8 & 05 & 5 & \\
\hline DPER & $9.07 \mathrm{E}-08$ & $9.45 \mathrm{E}-$ & 0.09595 & 0.9236 \\
& & 07 & 4 & \\
\hline DFIRM & -0.00305 & 0.00046 & -6.57502 & 0 \\
& & 4 & & \\
\hline R-squared & 0.24665 & Mean dependent var & 0.15809 \\
& 3 & & & 7 \\
\hline Adjusted R- & 0.16777 & S.D. dependent var & 2.42736 \\
squared & 3 & & & 8 \\
\hline S.E. of & 2.21372 & Sum squared resid & 8331.01 \\
regression & 9 & & & 7 \\
\hline F-statistic & 3.12693 & Durbin-Watson stat & 1.94410 \\
& 9 & & & 6 \\
\hline $\begin{array}{l}\text { Prob(F- } \\
\text { statistic) }\end{array}$ & 0 & & & \\
\hline & & & & \\
\hline
\end{tabular}

Based on Table 2 above, we have tested the existence of accrual discretion in the bullish and bearish time period in the Indonesian capital market. This finding shows that there are three independent variables of ROA, EPS and Size that are positively and significantly related to the accrual discretion in the bullish period. In addition, the average research variable is not significant.

The bonus scheme has a positive and insignificant effect on the accrual discretion in the bullish period of time in manufacturing companies. This can be seen in the coefficient value of 0.000000724 and P Value of 0.5446 . The number of outstanding shares also has a positive and significant effect on the accrual discretion in the period of bullish time in manufacturing companies. This can be seen in the coefficient value of 0.000000000621 and P Value of 0.4386 .

This research does not support the results found by (Pujiningsih, 2011; Pujiati and Arfan, 2013; Elfira, 2014), who find bonus schemes in Indonesian public companies have a positive effect on discretionary accruals.

Audit quality has a negative and insignificant effect on accrual discretion in the period of bullish time in manufacturing companies. This can be seen in the coefficient value of -0.00468 and $\mathrm{P}$ Value of 0.6462 . ROA has a positive and significant effect on the accrual discretion in the bullish period of time in manufacturing companies. This can be seen in the coefficient value of 0.005132 and P Value of 0.000 . PBV has a positive and insignificant effect on the accrual discretion in the bullish period of time in manufacturing companies. This can be seen in the coefficient value of 0.000841 and P Value of 0.55

EPS variables have a positive and significant effect on the accrual discretion in the period of bullish time in manufacturing companies. This can be seen in the coefficient value of 0.000178 and $\mathrm{P}$ Value of 0.000 . PER variable has a positive and insignificant effect on the accrual discretion in the period of bullish time in the manufacturing company. This can be seen in the coefficient value of 0.0000000090 and P Value of 0.92 . Otherwise, the firm size (F-SIZE) has a negative and significant effect on the accrual discretion in the bullish period of 
time in manufacturing of companies. This can be seen in the coefficient value of -0.00305 and $\mathrm{P}$ Value of 0.000 .

\section{Conclusion}

Based on the results of research data that has been found, the main purpose of this paper is to see how managers behave in delivering financial reports to the public. The bullish and bearish conditions on the capital market are very decisive for the company's performance and stock prices. When bullish, stock prices move in line with market developments, there is a considerable demand for stocks because investors have favorable expectations about the company's performance(Mehmood and Hanif, 2014).

In good macroeconomic conditions and increasing corporate performance stock prices tend to increase in positive trends (Usman, 2016). This bullish period investors will try to find the right momentum to be able to have stocks that have a fixed and definite return in the future. They assume, when the current performance is in good or bad condition, it will also affect future performance.

This research found evidence, when the capital market conditions were good, Indonesian manufacturing companies generally did not carry out discretionary accruals. In testing all research variables show a negative influence and significant independent variables on accrual discretion in the delivery of financial statements.

This study uses a dummy proxy to measure the bullish and bearish time period by taking IHSG data. At last for the future research use more measurable research instruments hopefully.

\section{References}

[1] Abukosim, Mukhtaruddin, Ferina, I. S. and Nurcahaya, C. (2014) 'Ownership Structure And Firm Values: Empirical Study On Indonesia Manufacturing Listed Companies’, Journal of Arts, Science \& Commerce, V(4), pp. 1-15.

[2] Bendickson, J., Muldoon, J., Liguori, E. and Davis, P. E. (2016) 'Agency theory: the times, they are a-changin', Management Decision, 54(1), pp. 174-193. doi: 10.1108/09574090910954864.

[3] Bernard, V. L. and Skinner, D. J. (1996) 'What motivates managers' choice of discretionary accruals?', Journal of Accounting and Economics, 22(1-3), pp. 313-325. doi: 10.1016/S0165-4101(96)00431-4.

[4] Dechow, P. M., Sloan, R. G. and Sweeney, A. P. (1995) 'Detecting earnings management', Journal of Accounting Research, 70(2), pp. 193-225. doi: 10.1111/j.1475-679X.2012.00449.x.

[5] Elfira, A. (2014) PENGARUH KOMPENSASI BONUS DAN LEVERAGE TERHADAP MANAJEMEN LABA, Research Report. Padang.

[6] Fairchild, R. (2010) 'Dividend policy, signalling and free cash flow: an integrated approach', Managerial Finance, 36(5), pp. 394-413. doi: 10.1108/03074351011039427.

[7] Ghazali, A. W., Shafie, N. A. and Sanusi, Z. M. (2015) 'Earnings Management: An Analysis of Opportunistic Behaviour, Monitoring Mechanism and Financial Distress', Procedia Economics and Finance. Elsevier B.V., 28(December), pp. 190-201. doi: 10.1016/S2212-5671(15)01100-4.

[8] Goel, S. (2015) 'Earnings management detection over earnings cycles: the financial 
intelligence in Indian Corporate', Sandeep Goe, 20(2), pp. 1-19. doi: http://dx.doi.org/10.1108/MRR-09-2015-0216.

[9] Grundei, J. (2008) 'Are managers agents or stewards of their principals? Logic, critique, and reconciliation of two conflicting theories of corporate governance', Journal fur Betriebswirtschaft, 58(3), pp. 141-166. doi: 10.1007/s11301-008-0038-2.

[10] Healy, P. M. (1985) 'The effect of bonus schemes on accounting decisions*', Journal of Accounting \& Economics, 7, pp. 50-107. doi: 10.1016/0165-4101(85)90029-1.

[11] Herbig, P. and Milewicz, J. (1996) 'Market signalling: a review', Management Decision, 34(1), pp. 35-45.

[12] Koerniadi, H. and Tourani-Rad, A. (2011) 'The role of accruals as a signal in earnings and dividend announcements: New Zealand evidence', Journal of Applied Accounting Research, 12(2), pp. 108-122. doi: 10.1108/09675421111160682.

[13] Mehmood, Y. and Hanif, W. (2014) 'Impact of Bullish and Bearish Market on Investor Sentiment', International Journal of Innovation and Applied Studies, 9(1), pp. 142151.

[14] Moustafa, M. A. (2015) 'The Separation of Ownership from Control and Firm Performance Evidence from UAE', Journal of Economic and Administrative Sciences, 21(2), pp. 35-51. doi: http://dx.doi.org/10.1108/MRR-09-2015-0216.

[15] Piyawiboon, C. (2015) 'Audit Quality, Effectiveness of Board Audit Committee and Earning Quality', Review of Integrative Business \& Economics, 4(2), pp. 366-377. doi: 10.1016/j.tox.2009.12.004.

[16] Pujiati, E. J. and Arfan, M. (2013) 'Struktur Kepemilikan Dan Kompensasi Bonus Serta Manufaktur Yang Terdaftar Di Bursa Efek Indonesia Tahun 2006-2010', Jurnal Telaah \& Riset Akuntansi, 6(2), pp. 122-139.

[17] Pujiningsih, A. I. (2011) Ukuran Perusahaan, Praktik Corporate Governance Dan Kompensasi Bonus Terhadap Manajemen Laba. Universitas Diponegoro.

[18] Reiter, S. (1997) 'The ethics of care and new paradigms for accounting practice', Accounting, Auditing \& Accountability Journal, 10(3), pp. 299-324. doi: 10.1108/09513579710178098.

[19] Richardson, S. A., Sloan, R. G., Soliman, M. T. and Tuna, I. (2005) 'Accrual reliability, earnings persistence and stock prices', Journal of Accounting and Economics, 39(3), pp. 437-485. doi: 10.1016/j.jacceco.2005.04.005.

[20] Usman, B. (2016) 'The Phenomenon of Bearish and Bullish in The Indonesian Stock Exchange', Esensi, 6(2), pp. 181-198. doi: 10.15408/ess.v6i2.3750.

[21] Yarahmadi, H. and Bohloli, A. (2015) 'Ethics in Accounting', International Journal of Accounting and Financial Reporting, 1(1), p. 356. doi: 10.5296/ijafr.v5i1.7829.

[22] Zgarni, I., Hlioui, K. and Zehri, F. (2012) 'Effect of the financial security law on real and accrual-based earnings management: an empirical evidence form Tunisia. - Free Online Library', Global Business and Management Research: An International Journal, 4(2), pp. 164-177. Available at: https://www.thefreelibrary.com/Effect + of + the + financial + security + law + on + real + and + a ccrual-based...-a0314801363 (Accessed: 11 January 2019). 